\section{COLLABORATION BETWEEN UNIVERSITY STAFFS AND STUDENTS}

$\mathrm{O}^{\mathrm{s}}$ October 13, a Conference was held in Bedford College to discuss matters of mutual interest to students and staffs of universities. The Conference arose out of the report of the Association of University Teachers on university developments and the report of the National Union of Students on the future of university and higher education, and was under the chairmanship of Sir Ernest Bimon, chairman of Council of the University of Manchester.

The Conference opened with a paper by Prof. S. Brodetsky (University of Leeds) on "The Financial Aspects of University Education". Prof. Brodetsky stressed the fact that the financial problem of the universities was no longer one for private action and private benefaction, but had become one facing the tax-payers of the country. It was particularly in connexion with capital expenditure that funds would have to be found from national resources. This became more apparent when it was realized that the recent increase in the Treasury Grant for current expenditure from $£ 2,150,000$ to $£ 4,150,000$ had been mainly absorbed in increasing the salaries of university staffs. The financial problem arising from possible and desirable expansion of universities was yet to be faced, and Prof. Brodetsky estimated that the national grant to universities should ultimately reach a figure of approximately $£ 15,000,000$ per annum. In this connexion, Prof. Brodetsky indicated that, in his view, there must be an increase in the numbers of students in universities, a rise in the standard of work, and a broadening of the fields in which university studies might properly be carried out. This would not, of course, mean a vast increase in the numbers of first-class honours people. In considering the expansion of university departments, Prof. Brodetsky indicated that caution would be needed to avoid all universities starting new developments in a haphazard way. Clearly this would need control, but "it would be contrary to the whole spirit of the freedom of British University life if each University were forced to adopt a policy laid down by a Committee under Government influence". Consultation between universities should accordingly be strengthened and some sort of advisory council should be established.

Prof. Brodetsky directed attention to the need for maintenance grants for all students to enable them to profit fully from their years at a university. The holding of a scholarship should be associated far more with the honour of academic achievement, rather than with financial reward. There had been signs that the term 'scholarship' had become cheapened. Finally, Prof. Brodetsky came to the question of residence of students. He urged an extension of residential facilities, and pointed out that both capital and current expenditure would be increased thereby.

The student's point of view was given by Mr. D. W. Seager (vice-president, National Union of Students), who drew the now familiar contrast between the willingness of the nation to spend money in war-time and its tendency to financial prudence in peace, particularly with regard to education, and called for an immediate increase of at least 50 per cent in the numbers of students, and a doubling of numbers as an early objective. Some 64 per cent of university students had come from the elementary schools, and in future ability, and ability alone, must be the governing factor to enable a boy or girl to go to the university. In some cases parents had been unwilling to allow their children to go on to the university because of the financial strain arising from the necessity for providing adequate money for personal expenditure. Parents had, moreover, tended to regard their student sons and daughters as "investments of flesh and blood paying dividends in later years". Mr. Seager contended that all grants to students should cover full fees and tuition, plus $£ 156$ per year living allowance, with an addition for London students. $\mathrm{He}$ further directed attention to the inequality of grants at present available from local education authorities.

The next session was devoted to methods of teaching, relations between staff and students, and facilities of the students' unions, and a paper was read by Mr. A. T. James (president, National Union of Students). Mr. James considered that there was a lack of co-ordination between university departments which was reflected in the teaching, which in different courses was not related, and gave the impression of a lack of connexion between one subject and another. Lecturing staff should work together as a team, with the object of presenting to their students a coherent picture of the whole subject. He urged more cooperation between staff and students at the departmental and faculty level. University staffs had resisted this on the grounds that they "were not going to be taught how to run their Departments by young people". He considered that the most severely strained relations usually existed between the officials of the students' unions and vice-chancellors and principals. University authorities had failed to realize that the outlook of the students' unions had materially changed during war-time, and that they now acted in a manner far more analogous to that of a trade union, considering the business of running a university to be at least as important as the running of social events and athletic activities. He confessed that this had provoked difficulties and would evoke still more in the future. While admitting that students in general are far more inexperienced in academic matters than are the staff, he was of the opinion that much more confidence might be placed in the students' ability to contribute valuable help to the running of a university, both as regards discipline and academic matters. The facilities of students' unions should be extended to cover all aspects of university life, and in particular the maintenance of the health of students.

Finally, Prof. R. Pascal (University of Birming. ham) dealt with "Urgent Tasks facing the Universities of Great Britain". He pleaded eloquently for the need for education in the wider sense and for a reconsideration of the syllabus of every specialism both in arts and science. Education in the arts faculties had been too subjective and in the science too narrow, and the group of social studies, in most cases more recently developed, should be excluded from the arts faculties.

Prof. Pascal provided a more detailed analysis than previous speakers of the reasons for an increase in the numbers of students, and for the need for a larger number of informed and active citizens. "In our larger civil services, in the youth services and social welfare, in education of adults and children, a far larger number of educated and trained people are 
needed." He considered that the great potential reserve of youngsters who might profit by a university education was to be found among the poorer income groups, and that it was essential that boys and girls of average ability from these lower income groups should be encouraged to go to the universities. They must accordingly be given maintenance grants

This increase in numbers would clearly take place by way of an increase in size of the 'provincial' universities rather than at Oxford, Cambridge, or London. He pleaded for an extension of really sound general courses leading to general degrees which would be suitable for the influx of students of average ability, and for a reconsideration of the method of admitting students, with a consequent revision of the functions of university appointments boards.

Finally, the Conference resolved as follows:

"In order to enable the Universities in this country to consult effectively over problems of general interest to all Universities, it is desirable that an Academic Universities Council be set up by the Universities, representative of and including members elected by the academic staffs of the different Institutions. The Council should have only advisory functions. The Conference urges that the matter be taken in hand as soon as possible in such a way as to include all the Universities in the country".

\section{FORTHCOMING EVENTS}

Monday, February 4

Roxal SocIETx of ARTS (at John Adam Street, Adelphi, London W.C.2), at 1.45 p.m.-Dr. S. G. "Hooker: "High Speed Flight" (Cantor Lectures, 3).

FARMERS' CruB (at the Royal Empire Society, Craven Street, Strand, London, W.C.2), at 2.30 p.m.-Mr. Robert Templeton: "Dehydration".

SOCIETY OF CHEMICAL INDUSTRY (joint meeting of the FOOD GROUP and the LONDON SECTION, at the Chemical Society, Burlington House, Piccadilly, London, W.1), at 6.15 p.m.- "The Treatment of Wate for Food Manufacturing Purposes"' (1) Mr. G. Carter : "Puriflcation of Water for Food Purposes"; (2) Mr. F, Howard and Dr. E. C. and Dr. E. I. Akeroyd: "The Role of Ionic Exchange in the Treatment of Water".

ROYAL GEOGRAPHICAL SOCIETY (at Kensington Gore, London, S.W.7), at 8 p.m.-Air Chief-Marshal Sir Philip Joubert and Lieut.in Support of Russian Convoys".

\section{Tuesday, February 5}

Confrerence on "Metalis Creep" arranged by the National Phyeical Laboratory, Teddington, from which permission to attend must be obtained (ar the Royal Society, Burlington House, Piccadilly, London, W.1). At 11.10 a.m. Prof. E. N. da C. Andrade, F.R.S.
"Introduction and History" ; at 12 noon-Mr. H. J. Tapsell : "Ex-
perimental Studies of Creep"; at 2.30 p.m.-Dr. W. Orowan perimental Studies of Creep"; at 2.30 p.m.-Dr. "E. Orowan: Control of Creep" ; at 4.30 p.m.-General Discussion (introduced by Sir Lawrence Bragg, F.R.S.).

Manchester Literary and PhILOSOPHICAL Soctetty (in the Reynolds Hall, College of Technology, Manchester), at $5.30 \mathrm{p} . \mathrm{m}$.Prof. P. M. S. Blackett, F.R.S. : Joule Memorial Lecture.

\section{Wednesday, February 6}

ROYaL SOCIETY OF MEDICINE (at 1 Wimpole Street, London, W.1), at 2.30 p.m.-Dr. E. Ashworth Underwood : "The Influence of Joseph Priestley on the Medical Thought of the 18th Century".

INSTITUTION OF ELECTRICAL ENGINEERS, RADIO SECTION (at Savoy Place, Victoria Embankment, London, W.C.2), at 5.30 p.m.-Dr. G. L. Grisdale and Mr. R. B. Armstrong : "Tendencies in the Design of the Communication Type of Receiver".

INSTITUTE OF FUEL (at the Institution of Mechanical Engineers, Storey's Gate, St. Janies's Park, London, S.W.1), at 6 p.m.-Mr. E. C. Evans: "The Utilisation of Waste Heat in Metallurgical Furnaces" (Industrial 'Waste Heat' Recovery Series, 7).

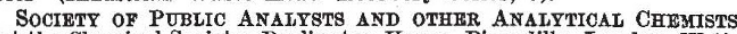
(at the Chemical Society, Burlington House, Piccadilly, London, W.1), at 6 p.m.- Scientifle Papers.

\section{Thursday, February 7}

Chrmiroar Socretr (at Burlington House, Piccadilly, London, W.1), at $5 \mathrm{pm}$ - - Scientiflc Papers, including a series by Dr. F. H. S. Curd and Dr. F. L. Rose on "Synthetic Antimalarials".

LINNEAN SOCIETY OF LONDON (at Burlington House, Piccadilly, London, W.1), at 5 p.m.--Scientifle Papers.
INSTITUTION OF ELECTRICAL ENGINEERS (at Savoy Place, Victoria
Embankment, London, W.C.2), at 5.30 p.m.-Mr. W. Fennell : "Fundamental Legislation covering the supply of Electricity to Consumers".

Society of Chemical Industry, Nottingham Section (in the Corporation Gas Theatre, Nottingham), at 7 p.m.-Dr. J. G. King "The Applications of Chemistry in Industry" (Jubilee M. Minorial Iecture).

\section{Friday, February 8}

ROYAL ASTRONOMICAL SOCLETY (at Burlington House, Piccadilly, London, W.1), at 4.30 p.m.- "Astronomical Telescopes" (Presidential Adress). Annual General Meetins.

PHYSICAI SOCIETY (in the Lecture Theatre of the Science Museum, Exhibition Road, London, S.W.7), at 5 p.m.-Prof. J. D. Cockcroft,
F.R.S.: "Rutherford-Life and" Work after the Year 1919, with Personal Reminiscences of the Cambridge Period" (Second 4 Rutherford Memorial Lecture).

Chemical Socterty (joint meetinglwith the UnIversity Chrmical SocIETx, in the Chemistry, Lecture Theatre, The University, Sheffield), at 5.30 p.m.-Mr. E. J. Bowen, F.R.S. : "Light Absorption from a Chemical Standpoint";

NORTH-EAST COAST INSTITUTION OF ENGINEERS AND SHIPBUILDERS (in the Lecture Theatre, Literary and Philosophical Society, Newcastle-upon-Tyne), at 6 p.m.--Dr. S. G. Hooker :" "Some Aspects of Gas Turbine Develonment for Aircraft Propulsion".

BRITISH Association of CHEMISTs, St. HEIENS SECTION (at the Y.M.C.A. Buildings, St. Helens), at 7.30 p.m.-Dr. J. Abrams : "Chemistry and Cancer".

ROYAL INSTITUTE OF CHFMISTRY (joint meeting with the CAMBRIDGR UNIVERSITY CHEMTOAL SOOIRTY and the FAST ANGLIA SECTION, in the main Lecture Room, University Chemical Laboratory, Pembroke Street, Cambridge), at 8.30 p.m.--Prof. A. Findlay : "The Organisation of Chemists"'.

\section{APPOINTMENTS VACANT}

ApPLICATIONS are invited for the following appointments on or before the dates mentioned :

CoUNTY ANALYST (which includes the offices of the Gas Examiner and Official Agricultural Analyst)-The Clerk, Worcestershire County Council, Shirehall, Worcester (February 8).

SENIOR ORGANIC CHEMIST for the Research Department of a large frm operating in N.W. England-The Ministry of Labour and National Service, Appointments Department, Technical and Scientific Register, Room 670, York House, Kingsway, London, W.C.2, quoting F.5001.XA (February 12).

Assistant Grease RESearch Chemist in the Bradford Sewage Department-The Town Clerk, Town Hall, Bradford (February 18) ASSISTANT SANITARY ENGINEERS (temporary)-The Ministry of Labour and National Service, Appointments Department, Technica and Scientiflc Register, Room (February 23)

PRINOIPAL OP THE WEST HAM MUNIOIPAL COLLEGE-The Education Officer, Education Offices, 95 The Grove, Stratford, London, E.15 (February 23).

PRIncIPAI-The Secretary to the Governors, Studley College, Studley, Yorks. (March 1).

County ANALyst-The Clerk, Middlesex County Council, Guildhall, Westminster, London, S.W.1 (March 16).

Professor of Chemistry - The Principal, Heriot-Watt College, Edinburgh (April 22).

JECTURERS (2) IN BACTHRIOLOGY : (1) with special experience and knowledge in VIRUS DISEASES, (2) with a general knowledge of BACTERIOLOaY-The Secretary, The University, Aberdeen (May 24). BIOCHEMIST (full-time, man or woman) for work in the Pearson
B BIOCHEMIST (full-time, man or woman) for work in the Pearson
Cancer Research Laboratory-The House Governor and Secretary, Metropolitan Hospital, Kingsland Road, Iondon, E.8.

TECHNICAL ASSISTANT to the ADVISORY BACTERIOLOGIST in conTECHNICAL ASSISTANT to the ADVISORY BACTERIOLOAIST in con-
nexion with the National Milk Testing and Advisory Scheme, Southern Province-The Advisory Dairy Bacteriologist, National Institute for Province-The Advisory Dairy Bacteriolog
Research in Dairying, Shinfleld, Reading.

Research in Dairying, Shinfleld, Reading.
ASSISTANT for abstracting, reviewing and indexing literature on ASSIsTANT for abstracting, reviewing and indexing literature on
forest products, stationed at Princes Risborough-The Director, forest products, stationed at Princes Risborough-The

Imperial Forestry Bureau, New Bodleian Building, Oxford. training in microanalytical work-Prof. G. F. Marrian, Department of Biochemistry, The University. Edinburgh.

Electro-CHeimist or a PHYSICAI CHBMist preferably with some knowledge of the corrosion of metals, and a METALLURGIST with industrial or research experience-The Secretary, British Non-Ferrous Metals Research Association, Euston Street, Iondon, N.W.1.

\section{REPORTS and other PUBLICATIONS (not included in the monthly Books Supplement) Catalogues}

Industrial and Scientiflc Instruments. (General Bulletin B.15.) Pp. 64. (London: Negretti and Zambra, n.d.)

The Book of Optical Glass Cells for Laboratory and Scientifle Work. Pp. 28. (Salisbury: The Tintometer, Itd., 1945.)

Johnson Indicator Papers. Pp. 12. (London: Johnson and Sons, 1945.)

Foreign Scientific and Technical Books reproduced by License of the U.S. Office of Alien Property Custodian. (Catalog No. 5.) Pp. 64 . (Ann. Arbor, Mich. : J. W. Edwards, 1945.) Books of Note. (Cata 